\title{
COXEN Score 5
}

National Cancer Institute

\section{Source}

National Cancer Institute. COXEN Score 5. NCI Thesaurus. Code C128202.

A score of 5 on the COXEN Sensitivity Scale. 